\title{
A Critical Review of Private Pension System in Turkey Considering the German System
}

\author{
Asst. Prof. Dr. Kemal Yaman (Mersin University, Turkey)
}

\begin{abstract}
Private pension system includes various measures met to continue existing living standards without any restrictions in old age, i.e. after the end of employment. High life expectancy, low birth rate, and institutional deficiencies in societies are major drivers for private pension. To understand seriousness of the topic mostly state pension claims are considered as being insufficient in old age. That's why, necessity of private pension products results. In the first part, theoretical approaches to the explanation of savings behavior of people are described. In the second part of the study, the situation concerning precautions taken in Turkey is examined. In the following part, the retirement arrangements in Germany are depicted for comparison. The financial situation of elderly people in both countries is analyzed. Financial sector is the key beneficiary of developments in both countries. Governmental regulations concerning retirement system play crucial role to achieve high level of prosperity in the national economy of many developed countries. It is also seen in the study that industrialized nations are characterized by considerable private pension funds. Finally; some conclusions are drawn from the analyses performed in the study. .
\end{abstract}

\section{Introduction}

Financial problems in the social security system reforms on restructuring in many countries and even in highly developed countries are unavoidable to pursue financial sustainability of the retirement system and to raise the economic activity in country. In many countries participation in private retirement system is voluntary except Chile, Switzerland, Mexico, and Hungary where contribution to private pension funds are mandatory (Gülsün and Hatunoğlu, 2012: 1). Large deficits in the pension system in Turkey has emerged an important policy option to reduce the load on the state budget caused by existing public pension system by implementing new strategies in private pension plans. In addition, reforms in the private pension system play significant role to prevent declining domestic savings in Turkey which present risk for macroeconomic stability. In the world, pension systems are based on the three pillars consisting of public, mandatory private, and voluntary private pension system. The first one is financed by public retirement system where private retirement system acts as supplementary. Publicly managed pension system based on a payroll tax which is the most common way for governments to support old people financially (TCMB, 2013: 3 and World Bank, 1994: 102).

According to report of World Bank, increasing life expectancy and falling fertility rates are main reasons for problems in pension system. As a result, retirement systems of such countries face challenge in financing its aging population by the decrease in the number of young people. That is to say, pensions of the elderly population are covered by premiums paid by working young people. Aging problem ends up in financing each retired old person by few working people. At last, in a situation such as this leads to financial crisis. Thus, a new model needs to be implemented against the danger of aging population (Alper, Emin, 2004: 3). Establishment of private pension system is necessary to provide additional financial support to the existing public social security system for pensioners during retirement period. So, additional income can be available to secure existing living standard, and long term systematic private savings will have positive effects on economic benefits to the society (Erdem, 2013).

Figure 1 provides conceptual basis for the model to be developed for retirement behavior. Starting point of the model is the assumption that the pension outlined in the sense of financial security for the retirement is a savings plan. To investigate the individual point of view of the retirement process, it is necessary to apply an integrative approach. That means, diverse knowledge of economical psychology should be considered. It is also necessary to define the considered decision situation clearly in whole decision-making process of retirement. Based on this information, the model depicted in figure 1 includes two basic components.

- Financial qualification and willingness to make arrangements for retirement. These pension plans should be based on the consumption and savings model of Georg Katona.

- The so-called psychological triad.

The retirement ability is affected by economic variables; that's why it is primarily determined according to the income situations. This group of factors is directly measurable. However, the willingness to pension plan depends on psychological influences. Under this should be all non-economic variables understood that may contribute to the explanation of retirement behavior (Salek, 2010). 


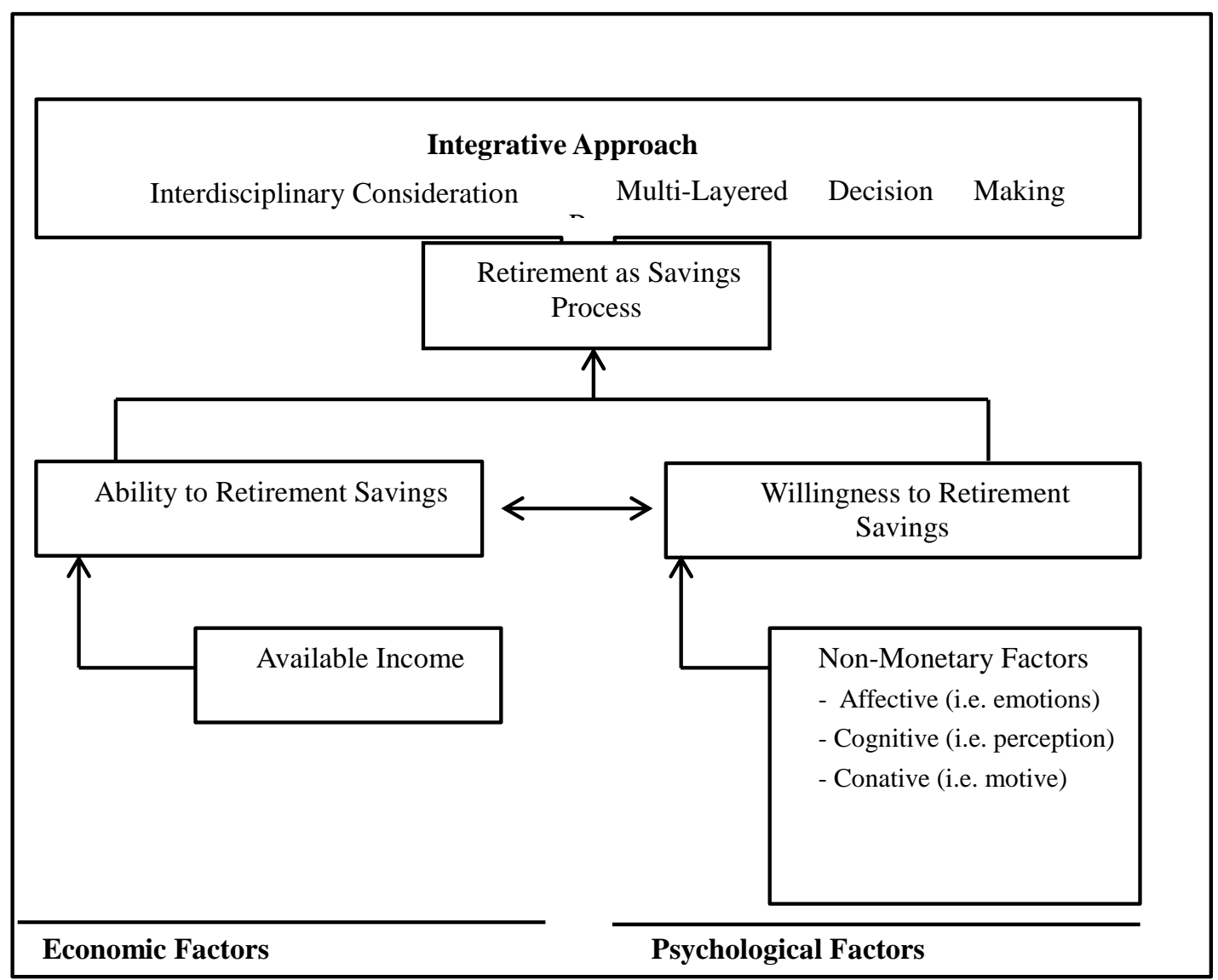

Figure 1: Model for Behavior of Retirement Savings (Salek, 2010: 53)

Figure 2 shows theoretical system of factors influencing the willingness for pension plan which should be examined in this study. As outlined in this figure; economic, social, and psychological factors are fundamental.

Economic factors:

behavioral science

- Disposable income

Psychological factors:

Socio-demographic factors:

- Affective

- Cognitive

- Age

- Conative

- Gender

- Occupational status

- Marital status

- Education

Figure 2: Theoretical system of factors influencing the willingness for pension plan

\section{Theoretical Approaches to the Explanation of Saving Behavior}

\subsection{Life-Cycle Hypothesis}

Employment and retirement phases are two important economic phases of a life cycle. The key assumption of the life cycle model is that individuals are forward-thinking and they also make and realize optimal consumption planning over their entire life cycle. To cushion intertemporal income fluctuations are main motives for 
formation of savings. Other saving motives are precautionary savings, savings for purchase of durable consumer goods, and inheritance motives (Leinert, 2005: 15).

The neoclassical approaches experienced a renaissance with the life-cycle hypothesis of Modigliani and Brumberg as well as with the hypothesis of permanent income by Friedman. Distribution of income between present and future consumption is an active decision based on neoclassical approaches determined by assets and interest rate. Hypothesis of permanent income included in life cycle hypothesis reveals that people have an idea about the amount of long-term income as well as they want to maintain a certain and constant consumption level. Life cycle hypothesis highlights savings motive for retirement arrangement explicitly. Life cycle hypothesis supposes two strict assumptions comprising the rational behavior and perfection of the market. Aim is optimal distribution of consumption to remaining lifetime by given financial resources consisting of current income, assets, and expected income development. That means that working people in middle age save money in case of high earned income and finally consume accumulated capital stock in retirement. Young people also take loan if their financial situation is not enough to fund desired intentions but expected income development makes repayment possible. Since individual is rational, it is presumed that he/she can always estimate his/her lifetime earnings and he/she has an idea of the future income situation (Salek, 2010).

But, empirical evidence is against the predictions assumed in the life cycle model. So, these assumptions cannot be confirmed. Comprehensive findings deny lifelong planning horizon and show that level of consumption follows the level of income. That is to say, consumption responds to short-term income change (Leinert, 2005; Salek, 2010 and Thaler, 1990). Observed consumption and saving behavior of individuals deviate in all life stages for considerable part of households from central predictions of life cycle models (Salek, 2010: 36):

1. Young households often show positive saving ratios and low borrowings.

2. Many households estimate their future income incorrectly so that they take loans due to intensive consumption, and as a consequence they become insolvent.

3. In retirement people in Germany do not completely consume available assets including real estate. Majority of households of pensioners save money where, at first view, this behavior of old age people is theoretical explained by inheritance motives. But, empirical evidence shows that retired people with or without kids have no asset discrepancies. So, savings behavior of old people is not motivated by inheritance.

\subsection{Behavioral Life-Cycle Hypothesis}

From psychological perspective elements of behavioral effects are analyzed in the context of life-cycle hypothesis. People face problems in self-control, that's why they are hindered at realizing the intension of pension plan. Thaler and Shefrin considered three elements in their discussion of self-control: temptation, willpower, and internal conflict. Temptation is seen as a significant element to explain savings behavior of people. This element is understood as the ability to delay satisfaction to decrease the conflict between abrupt satisfaction and long-term benefits. It is also possible to state self-control as a behavioral cost (Huang, 2007 and Shefrin and Thaler, 1988). So, forgoing consumption is painful and uncomfortable. That's why; it requires effort and willpower to control themselves. Thus, control mechanisms such as mental accounts are used to limit propensity to consume (Salek, 2010). Each person recognizes income change different mentally. Small money entry is assigned to permanent income which is consumed promptly. But, unexpected money entrances are assigned to assets which are spent cautiously. This behavior of people can be characterized by higher savings tendency of asset account than income account (Winnet/Lewis, 1995 and Salek, 2010).

\subsection{Pension Model of Leinert}

Pension model of Leinert describes retirement savings behavior from psychological-behavioral aspect as shown in Figure 3. Central question in the approach of Leinert is under which conditions the intension for the pension plan and retirement savings should be realized. The deciding factor is a comparison of advantages and disadvantages associated in each phase. This process is similar to the economic cost-benefit analysis and that's why to what extent it is worth to perform actions such as planning and savings should be questioned. During retirement planning following costs; i.e., monetary planning costs for using a pension consulting, time usage as planning cost for consultation and information search, and at last psychological costs resulting from possible reluctance to financial matters arise (Salek, 2010).

Retirement planing starts by engaging with the topic of retirement. Implementation is carried out in cognitive processes focusing on the financial resources and future needs from which necessary amount of savings contribution is determined. For the next step of retirement savings also exclusive intension is required. Application is done by choosing appriopriate pension product considering results of retirement planing. It is obvious that voluntary retirement procedure consists of four stages. Each stage is analytically separated and in each stage termination of retirement process is possible if the cost-benefit analysis is negative. Once all four stages are successfully completed, then increased retirement savings occur (Salek, 2010: 37 and Leinert, 2005). 
- Analysis of current financial options

- Determination of expected retirement income

- Estimation of need for retirement

- Decision whether and to what extent it should be saved
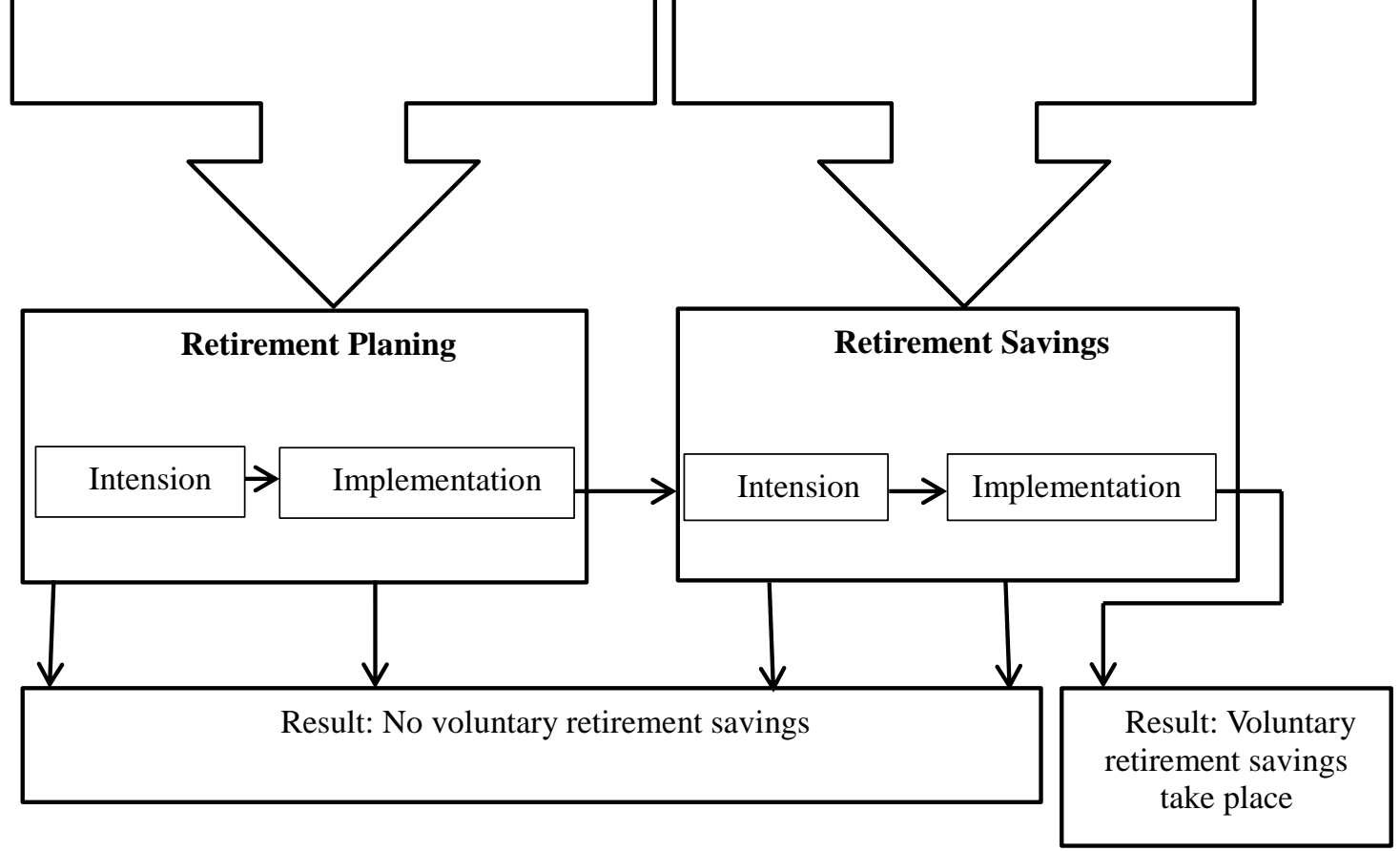

Figure 3: Retirement Process from Leinert (Salek, 2010: 38 and Leinert, 2005: 73)
- Selection of a suitable savings products in the financial market

- Conclusion of a retirement contract

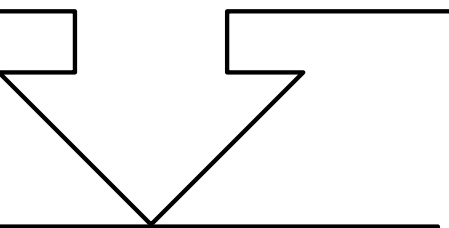

Retirement Savings

After introducing important theoretical approaches for the explanation of savings behavior of people, the situation concerning pension system in Turkey and Germany is analyzed.

\section{Precautions Taken in Turkey Regarding Pension System}

Private pension system in Turkey was regulated by the law no.4632 named 'Private Pension Savings and Investment System Law' introduced on October 7, 2001 as a supplement to the public social security system. Aim of this law was to direct individuals savings to investment for retirement to provide extra income for raising the level of prosperity. In addition, such a law targeted to offer long-term financial resources in order to increase employment and support economic development. Hereby, tax incentives were introduced to motivate people for participating in private pension system and at the same time in order to prevent leaving pension system entitlement to pension benefits are restricted and in some cases blocked. Considering problems in private pension system, a law came into force on January 1, 2013 to increase private savings. So far existing tax incentives in the form of deductions from taxes paid for received income has been replaced with this new law by introducing $25 \%$ state contribution. For Example, 100 TL pension premium is supported by state contribution of 25 TL (Emeklilik Gözetim Merkezi, 2008).

Regulations were implemented concerning taxation of income received in the private pension system. In order to encourage people to stay for a long time in the pension system, entitlement to the state contribution is gradually enabled. So; people have claim on state contribution and its gains in the $3^{\text {rd }}$ year to $15 \%$, in the $6^{\text {th }}$ year to $35 \%$, in the $10^{\text {th }}$ year to $60 \%$, and finally in retirement to $100 \%$. It is clear that private pension system enables raising funds by preventing short-term speculative capital movement leading to financial crisis or at least to lessen the depth of the crisis. Worldwide private pension system provides financial resources to capital markets and it is expected that these funds will bring dynamism to the economy of the country in long term. Social security problems in Turkey are not demographic because of its young and dynamic population. Problems in this area are rather based on actuarial imbalance and institutional deficiencies leading to financial problems (Gülsün and Hatunoğlu, 2012). 
Private pension system in Turkey does not have a long history, that's why it is also not so developed compared to other industrialized countries which can be seen from Figure 4. It can be clearly seen that developed countries with strong social security system such as Norway, Sweden, France, Luxembourg, and Germany show low private pension rate as a percentage of Gross Domestic Product (GDP). This may be explained by trust of inhabitants to their public security systems. But even in countries such as Finland and Switzerland with solid social security system, share of pension funds in GDP is remarkably where in Switzerland $114 \%$ and in Finland $79 \%$ of GDP is invested by people for hard times in retirement. Countries like Turkey made up just 4\% of GDP in 2012 where a strong social security system is not available. Hereby, it is seen that Turkey a developing country has big potential to raise its pension funds due to its weak social security system.

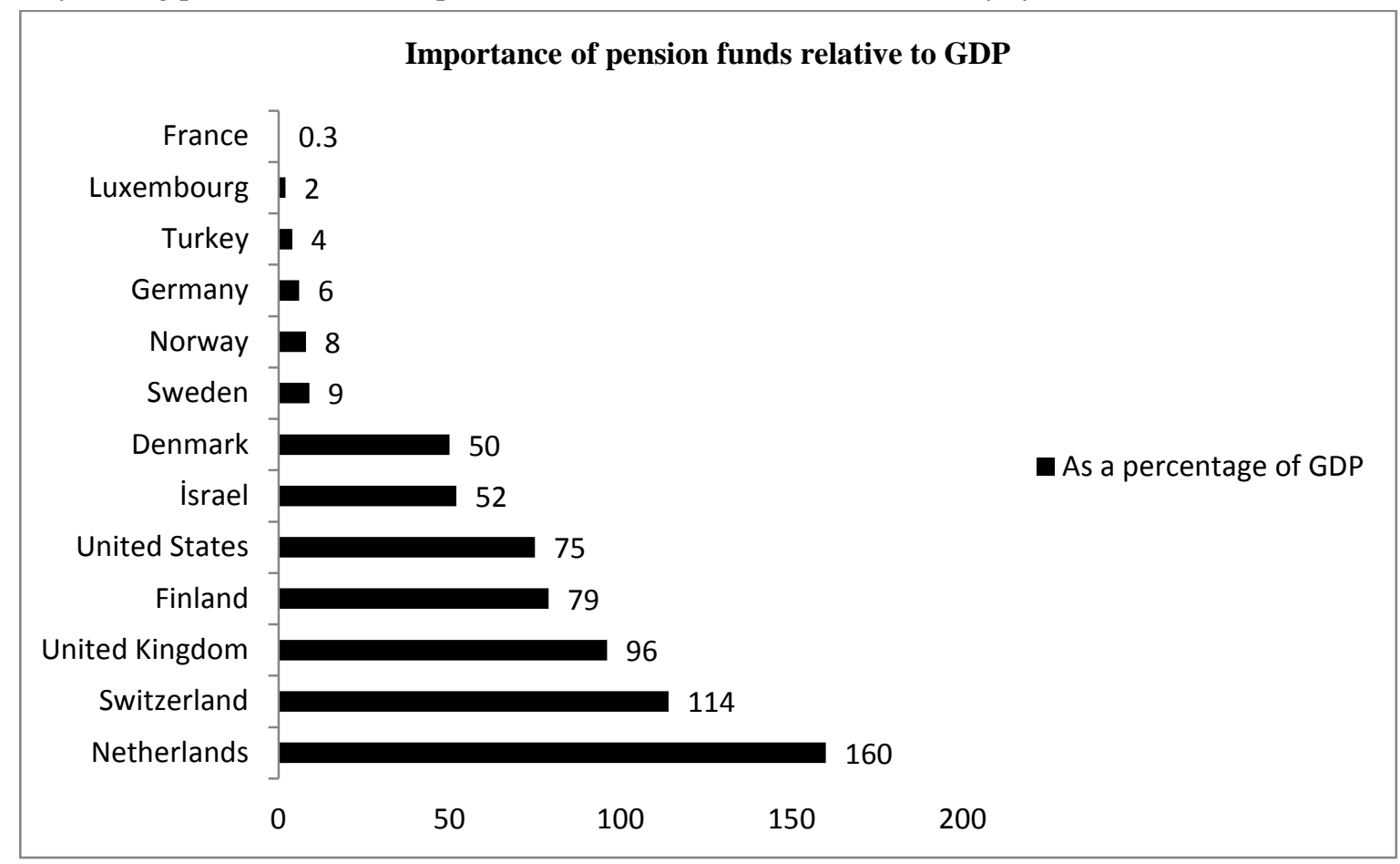

Figure 4: Importance of Pension Funds Relative to the Size of the Economy in Selected OECD Countries in 2012

Furthermore, the economic strength or purchasing power plays important role to achieve such a goal. For this reason, purchasing power in Turkey needs to be investigated. Gross Domestic Power was 792.6 billion USDollars in 2012 and because of 75,627,384 inhabitants in Turkey (TUİK, 2012) purchasing power per head was 10,481 US-Dollars. It should be noticed that regions in Turkey are inadequately developed. This corresponds to an amount of 7,944 Euros at the end of 2012 (TCMB, 2014). According to a report, about 30\% of GDP was obtained in Istanbul (Doğan, 2013: 539). Considering this fact purchasing power per capita in İstanbul, Ankara, İzmir, and Antalya is higher than in relatively less developed cities in east and south eastern areas of Turkey. Consequently, demand for products of private pension in developed cities is higher. Economic power of inhabitants in Turkey is too weak compared to people in Germany. That's why retirement system in Turkey is not so developed as desired. In a development report of private pension system the number of completed private pension contracts in Turkey are depicted. These numbers clearly show disparity in purchasing power in Turkey. So, $45 \%$ of contracts are completed in the Marmara region (North-West Turkey, i.e. İstanbul), 15\% in the Central Anatolia region (i.e. Ankara), $16 \%$ in the Aegean region (i.e. İzmir), $12 \%$ in the Mediterranean region (i.e. Antalya), $7 \%$ in the Black Sea region, $3 \%$ in the Southeastern region, and just $2 \%$ in the East region of Turkey (Emeklilik Gözetim Merkezi, 2012: 17). From the same report, it follows that $61.3 \%$ of completed contracts are made by men and $38.7 \%$ by women. Thus, economic power of women should not be underestimated (Emeklilik Gözetim Merkezi, 2012: 31).

In the next step development of private pension system is investigated. Hereby, it is clear that from 2004 until 2014 the number of contracts in Turkish private pension system has increased more than tenfold. These numbers show that people in Turkey are aware of poverty in old age. As soon as suitable circumstances are available for pension fund accumulation people actualize it. As can be seen above, in economically developed regions such Marmara region in which $45 \%$ of existing contracts are completed, people tend to purchase such products. Certainly, the role of Turkish State should not be underestimated by implementing new techniques to make pension system more and more attractive for its citizens. So far, existing tax incentives in the form of deductions from taxes paid for received income has been replaced with this new law by introducing $25 \%$ state contribution. 
But, the main problem in Turkey is weak economic performance of people which can easily be recognized from per capita income. Thus, savings rate is low in Turkey. In regions where people hardly survive financially, naturally they are not able to put money aside for old age.

\begin{tabular}{|r|r|c|c|c|c|c|c|l|}
\hline $\mathbf{2 0 0 4}$ & $\mathbf{2 0 0 5}$ & $\mathbf{2 0 0 6}$ & $\mathbf{2 0 0 7}$ & $\mathbf{2 0 0 8}$ & $\mathbf{2 0 0 9}$ & $\mathbf{2 0 1 0}$ & $\mathbf{2 0 1 2}$ & $\mathbf{1 4 . 0 2 . 2 0 1 4}$ \\
\hline 334,557 & 714,146 & $1,141,428$ & $1,576,273$ & $1,933,266$ & $2,203,886$ & $2,534,840$ & $3,496,377$ & $4,278,414$ \\
\hline
\end{tabular}

Table 1: Development of number of contracts in pension system (Emeklilik Gözetim Merkezi, 2013)

Examining number of contracts and total contributions in the period between 2004 and 2014, it becomes clear that number of contracts and total contributions in private pension system show the same tendency. In 2004 contributions made up just 157.4 million Euros where in 2014 it has reached 8.56 billion Euros. In the same time period contributions grow fifty-five times (see Table 1 and 2).

\begin{tabular}{|l|c|l|l|l|l|l|l|l|c|}
\hline & $\mathbf{2 0 0 4}$ & $\mathbf{2 0 0 5}$ & $\mathbf{2 0 0 6}$ & $\mathbf{2 0 0 7}$ & $\mathbf{2 0 0 8}$ & $\mathbf{2 0 0 9}$ & $\mathbf{2 0 1 0}$ & $\mathbf{2 0 1 2}$ & $\mathbf{1 4 . 0 2 . 2 0 1 4}$ \\
\hline TL (in million) & 288.3 & $1,117.2$ & $2,592.5$ & $3,917.1$ & $5,467.7$ & 7,102 & $9,515.2$ & 17,282 & $25,663.2$ \\
\hline Exchange rate & 1,8321 & 1,5952 & 1,8604 & 1,7142 & 2,1435 & 2,153 & 2,065 & 2,3565 & 2,9974 \\
\hline Euro(in million) & 157.4 & 700.4 & $1,393.5$ & $2,285.1$ & $2,550.8$ & $3,298.7$ & $4,607.9$ & $7,333.7$ & 8,562 \\
\hline
\end{tabular}

Table 2: Development of contributions in pension system (Emeklilik Gözetim Merkezi, 2013 and TCMB, 2014)

In order to identify the effect of pension system on a country's economy, examination of pension fund asset allocation for selected investment categories in selected OECD countries is required. Hereby, investment categories are shares, bills and bonds, cash and deposits, and others. In 2012, bonds (representing bills and bonds) and equities were the two most preferred asset classes for invested pension funds. In the USA 48.9\%, in Australia 46\%, in Finland 37.1\%, in Germany about 5\%, and in Turkey around 18\% of total investments are allocated to stocks. The investment approach of German insurance companies show more reserved behavior against stocks, whereas Turkish companies are more open for investments in more risky instruments. Bills and bonds are fixed income securities with more guaranteed returns. That's why, in over half of the OECD countries more than $50 \%$ of pension funds are invested in bills and bonds. In 14 OECD countries; Turkey, Germany, Iceland, Israel, Luxembourg, Norway, Poland, the Slovak Republic, Slovenia, Spain, Sweden, Austria, Chile and Denmark; more than 50\% of portfolio was invested in bills and bonds in 2012. Percentage of invested funds in bills and bonds make up more than three-quarter of total investments in Czech Republic with 85.4\%, in Hungary $84.6 \%$, and in Mexico 80.9\%. Other investment tools constitute around $42 \%$ in Germany and around $18 \%$ in Turkey. Finally, proportion of cash and deposits in pension fund portfolios is not more than 5\% in Turkey as well as in Germany. It is obvious that pension funds are invested in financial market products, so its contribution is of great importance for the economy of a country (OECD, 2013:19). Examination of Turkish households' savings rate indicate a declining trend of $17.7 \%$ to $7.3 \%$ from 2003 to 2010 (TCMB, 2013: 14).

\section{Retirement Arrangements in Germany}

Retirement system in Germany is based on the so-called three pillars: Statutory pension system, occupational pension system, and private pension system. Statutory pension system is based on the principle of distribution. That means, contributions paid are not saved but these are used for pension payments to current retirees. Thus, it has no claim for refunding of already paid contributions. Younger generation comes up for the pension of old generation. This is based on the principle of solidarity. Due to aging population in Germany and decreasing fertility rate, less working people will have to fund gradually increasing number of retired people. As a result of increasing life expectancy people living longer are financed by decreasing number of social security contributors. To close the pension gap emerging by the cuts in legal services, it is therefore necessary to build significant additional savings. There are indications that savings for retirement will show an increase. However, previous experiences in Germany show that majority of the population do insufficient individual retirement arrangement despite existing resources as well as in spite of widespread recognition of the necessity of individual responsibility (GDV, 2004).

As a consequence of this age pyramid, pension contributions of working people will increase more and more in the future. The lacks in social security system force state to implement new instruments to increase living standards in retirement. Second pillar, so-called occupational pension system (betriebliche Altersvorsorge), is possible for working people as soon as their employers grant their employees' pension commitment. Since January $1^{\text {th }}, 2002$ employees basically have the right to convert part of their wages in an equivalent pension commitment (Statistisches Bundesamt, 2014). In addition, company pension is supported by tax incentives to strengthen this type of retirement scheme. Every employee in Germany is legally entitled to occupational pension system. But, this does not mean that every employer has to pay pension as it is common for larger companies. Mostly a part of the annual salary such as monthly wage or holiday payment as well as Christmas bonuses, and special payments can be converted into company pension. As a general rule, employer transfers money directly from the gross salary so that taxable income decreases. Thus, employee enjoys tax privileges. As 
a consequence, people have tax advantage from this application. By the end of 2004, completed contracts reached 2,640 Euros tax and social security contribution-free in principle. Starting from 2005, contracts have received tax benefits around 4450 Euros per annum. Payment of pension by company to employee is guaranteed.

Additional contributions for statutory pension and health insurance shrink. As a consequence, if the employee's income is subtracted 200 Euros for occupational pension by company employee's net income will be about 100 Euros less. That means, net salary decreases only by about half of transferred gross salary. Although occupational pension system offers several financial advantages compared to other forms of investment, only one in every three persons of German employee has occupational pension. Even though occupational pension is offered by employer to $60 \%$ of population in Germany, only 29\% take advantage of it (Stern, 2013 and Süddeutsche Zeitung, 2011). If expressed in numbers, the number of active pension rights in occupational pension has increased from 14.6 Mio. in 2001 up to 19.6 Mio. in 2011(Bundesministerium für Arbeit und Soziales, 2012: 134). Statistics show that even young people are less interested in occupational pension where they should have been more arranged for their retirement because of decreasing services offered by German state to retired people. That's why young people should expect much less from the state concerning statutory pension (GDV, 2004: 77). Total premium income in 2011 for occupational pension reached 13.8 billion Euros. According a report of the auditing firm of PWC, occupational pension market in Germany is the largest and most attractive opportunity field (Versicherungsmagazin, 2012).

Another type for financing retirement is the private pension, the so called 'Riester-Rente' in German language. Beyond the measures to promote occupational pension, tax-subsidized and fully funded (i.e., backed by a fund of assets) pension scheme Riester-Rente was implemented in 2002. This provides a possibility to compensate the unavoidable pension cut of statutory pension insurance given the forecasted demographic development in Germany. Riester-Rente is designed as a voluntary additional pension scheme. By the end of June in 2012, the number of Riester contracts were around 15.6 Mio. However, it should be realized that the number of newly completed contracts were only 0.2 Mio in 2012. The reasons of this situation are mainly found in the financial market crisis leading to an increasing skepticism towards fully funded retirement system. Even though there is a big demand for Riester-Rente, total premiums (own contributions plus allowances) of the funded pension contracts in 2009 were around 8.1 billion Euros. (Bundesministerium für Arbeit und Soziales, 2012: 141-149).

In 2011, each German citizen paid nearly 2,000 Euros in average for his/her private insurance coverage. Half of this sum accounted for life insurance, i.e. private pension. For contracts of property and casualty insurance such as automobile insurance, private liability insurance, legal protection insurance, building and households contents insurance each German citizen spend on average 450 Euros per year. People in Germany pay 400 Euros in average per annum for private health insurance. However, this contribution may vary in case of statutory health care where the contribution is determined by a certain percentage of between $14 \%-16 \%$ of received income. In 2011, premium income in life insurance pension reached 86.8 billion Euros (GDV, 2012: 4). In total 92.6 million contracts for the intention of pension were completed such as life insurances and pension funds (GDV, 2012: 24)

Table 3 presents the development of premiums received from life insurance including pension funds where an obvious increase is recognized from 2004 to 2010. In addition, private savings of households and the savings rate in percentage of disposable income as well are shown. It becomes clear that private savings grew up to 180.3 billion Euros in 2008. As a result of financial crisis in Germany, the savings rate of households decrease starting from 2008. That's why, private savings declined from 180.3 in 2008 to 172.6 in 2011.

\begin{tabular}{|c|c|c|c|}
\hline Year & $\begin{array}{c}\text { Premiums received in Life Insurance } \\
\text { incl. pension funds (billion Euros) }\end{array}$ & $\begin{array}{c}\text { Private Savings } \\
\text { (billion Euros) }\end{array}$ & $\begin{array}{c}\text { Savings rate of } \\
\text { Households (in \%) }\end{array}$ \\
\hline 2004 & 70.3 & 151.8 & 10.6 \\
\hline 2005 & 75.2 & 156.9 & 10.7 \\
\hline 2006 & 78.5 & 162.5 & 10.8 \\
\hline 2007 & 79.0 & 168.1 & 11.0 \\
\hline 2008 & 79.7 & 180.3 & 11.5 \\
\hline 2009 & 85.2 & 170.1 & 10.9 \\
\hline 2010 & 90.4 & 174.7 & 10.9 \\
\hline 2011 & 86.8 & 172.6 & 10.4 \\
\hline
\end{tabular}

Table 3: Contribution in Life insurance, Private Savings, and Savings Rate (GDV, 2012: 28)

To compare per head income of the population in Turkey with people living in Germany the need for consideration of gross domestic product in 2012 results. The monetary value of all the finished goods and services produced in Germany reached 2,645 billion Euros (Statistisches Bundesamt, 2013: 2). At the end of 2012, the number of inhabitants was 80.5 million (Statistisches Bundesamt, 2012) so that per capita income was 32,857 Euros. People in Germany have four times more income than individuals in Turkey. 
Analysis above show that people in Germany do much more for retirement but at the same time Germans still worry so much about their pension. This is due to bad news from financial markets as they know that big part of their pension funds are invested in financial market products. According a report of the German newspaper Süddeutsche Zeitung, this unstable situation in Germany is the consequence of implementation of rescue packages of troubled banks by the German government and the circumstances of the German stock market. In principle, bankruptcy of a life insurance company is possible but practically rather improbable. Moreover, badly managed corporations are usually taken over by other companies. If a company becomes insolvent bailout fund called Protektor helps out. All licensed insurance companies in Germany have to pay to the bailout fund. As a consequence, Protector takes over the payments of existing contracts in bad times and continues the management of these contracts such as the case of the Mannheimer life insurance company. In 2002, Mannheimer registered a loss of nearly 60 million Euros because of failed stock speculation. Only promised guaranteed interest rate was paid to the customer but no surpluses. Surpluses are paid to contract holders when the insurer invests the capital of customers in lucrative investment assets. Because of the financial crisis, insurance companies may face the problem of earning guaranteed interest rate which is promised to contract holder in life insurance contract. That is the reason why they reduced the proportion of the shares in investment products. At the same time, risk-free investment products such as government bonds are not very attractive due to the low-interest policy of central banks (Süddeutsche Zeitung, 2010).

\section{Results}

Social security system plays import role for people to maintain existing living standards. In general, statutory retirement system is not sufficient to achieve this goal. Theoretical basis demonstrate that intention alone is not sufficient to take appropriate measures for pension. Circumstances play major role in realizing their purpose such as available income, assets, expected income, governmental assistance, tax allowance, and psychologicalbehavioral perspective.

In comparison to the available system in Turkey, a well-developed statutory retirement system exists in Germany. As a result of aging population and increasing expectancy of life, more and more retired people have to be financed by decreasing number of working people because of falling fertility rate in Germany. So, German people tend to take additional measurements to continue their economic status. In addition to the existing statutory system, analysis of German private retirement market show that people put aside 1000 Euros for retirement per annum. Premiums received in life insurance made up for instance in 2010 more than 90 billion Euros and occupational pension system reached nearly 20 billion Euros in 2011. Riester-Rente is another type of private pension in which 8.1 billion Euros were received in 2009. Per head income highlights the economic situation of individuals' in both countries: German people earn four times more than individuals in Turkey. Economic power of Turks indicates their weak position regarding retirement. That's why; a weak private retirement market in Turkey exists. Governmental arrangements in Turkey such as introducing 25\% state contributions are realized to improve the miserable situation in private pension market. The new regulation helps to increase pension contribution from 157.4 million Euros in 2004 up to 4.6 billion Euros in 2010. Increasing trend continues and it reaches 8.56 billion Euros on February $14^{\text {th }}, 2014$. Nearly 20 times more pension contributions were received in Germany than in Turkey in 2010. Germany shows better development concerning private pension system than Turkey. But in comparison to Netherland, Switzerland, and United Kingdom as a percentage of GDP, Germany indicates very low share with 6\% of GDP where this rate reaches $160 \%$ in Netherlands. This paper shows a big potential of growth for Germany and for Turkey with $4 \%$ private pension fund of GDP. Turkish pension market indicates growing tendency, but the weak economic power in Turkey is the main reason for this phenomena. As soon as people have financial resources and incentives to savings are available, they have a tendency to invest in pension system for old age. Governmental regulations concerning retirement system play crucial role such as Riester-Rente and occupational pension system (betriebliche Altersvorsorge) in Germany as well as $25 \%$ state contribution in Turkey. To achieve high level of prosperity in national economy, measures taken by governments concerning retirement system are of great importance. It is also seen in the study that industrialized nations are characterized by considerable private pension funds.

Growing economy in Turkey may provide investment possibilities to German insurance companies in prosperous sectors such as energy, banking, and production of industrial goods due to its dynamic, young, and well-educated population in Turkey. As stated above, German insurance companies possess a big amount of capital and these companies are looking for lucrative investments. Lucrative sectors in Turkey can attract much more capital from German companies. Turkish markets need more investments in order to raise the economic power of their inhabitants and German companies need more profitable investment areas to meet their obligations to insurance contract holders regarding guaranteed interest as stated in contract.

\section{References}

- Alper, 2004. Emeklilik reformları: Dünya Bankası, Avrupa Birliği ve Türkiye. Boğaziçi Üniversitesi Sosyal Politika Forumu. Araştırma Raporu Research Papers. http://www.spf.boun.edu.tr/docs/discussionpaper3.pdf. 
- Bundesministerium für Arbeit und Soziales, 2012. Ergänzender Bericht der Bunderregierung zum Rentenversicherungsbericht 2012 gemä $\beta$ 154 Abs. 2 SGB VI (Alterssicherungsbericht 2012). http://www.bmas.de/SharedDocs/Downloads/DE/PDF-Gesetze/alterssicherungsbericht_2012.pdf?_blob= publicationFile.

- Doğan, 2013. Geçmişten günümüze http://www.marmaracografya.com/pdf/27.24.pdf.

- Emeklilik Gözetim Merkezi, 2008. Bireysel Emeklilik Sistemi. http://www.egm.org.tr.

- $\quad$ Emeklilik Gözetim Merkezi, 2013. Bireysel Emeklilik Sistemi Gelişim Raporu 2012. http://www.egm.org.tr/bes2012gr.asp.

- $\quad$ Emeklilik Gözetim Merkezi, 2013. Bireysel Emeklilik Sistemi 2004, 2005, 2006, 2007, 2008, 2009,2010 ve 2012 Y1lı Gelişim Raporu. http://www.egm.org.tr/?pid=360.

- Erdem, 2013. Bireysel Emeklilik Sistemine Yönelik Değişikliklerin Eleştirisi, http://tbbdergisi.barobirlik.org.tr/m2013-104-1243.

- Gesamtverband der Deutschen Versicherungswirtschaft (GDV), 2004. Die Märkte für Altersvorsorge in Deutschland - Eine Analyse bis 2020. Schriftenreihe des Ausschusses Volkswirtschaft 23. http://www.gdv.de/wpcontent/uploads/2011/11/Broschuere_Maerkte_fuer_Altersvorsorge_in_Deutschland_bis-2020.pdf.

- Gesamtverband der Deutschen Versicherungswirtschaft (GDV), 2012. Jahrbuch 2012. Die deutsche Versicherungswirtschaft, http://jahrbuch.gdv.de/GDV-Jahrbuch2012.pdf.

- Huang, Yanjun (2007). Testing the Behavioral Life_Cycle Model for Saving and Consumption, http://edissertations.nottingham.ac.uk/1174/1/07MAlixyh10_(2)YanYun.pdf.

- İşseveroğlu and Hatunoğlu, 2012. "Türkiye'de Bireysel Emeklilik Sisteminin Makro Ekonomik Dinamiklere Etkisi Kapsaminda Swot Analizi“, in Muhasebe ve Finansman Dergisi, Ekim 2012, p. 155-174.

- Leinert, 2005. Altersvorsorge: Theorie und Empirie zur Förderung freiwilligen Vorsorgesparens, Univ., Diss., Berlin, http://www.econbiz.de/Record/altersvorsorge-theorie-und-empirie-zur-f\%C3\%B6rderungfreiwilligen-vorsorgesparens-leinert-johannes/10003182795.

- Organisation for Economic Co-operation and Development (OECD), 2013. Pension markets in focus 2013. http://www.oecd.org/pensions/PensionMarketsInFocus2013.pdf.

- Salek, 2010. Rahmenkonzept für Altersvorsorgeforschung zur Modellierung der Altersvorsorgebereitschaft Psychologische Ansätze und empirische Untersuchung, Karlsruhe, http://digbib.ubka.unikarlsruhe.de/volltexte/1000020383.

- Shefrin and Thaler, 1988. "The Behavioral Life-Cycle Hypothesis", in: Economic Inquiry, Volume 26, Issue 4, p. 609-643.

- Statistisches Bundesamt, 2013. Pressekonferenz - Bruttoinlandsprodukt 2012 für Deutschland. Wiesbaden, https://www.destatis.de/DE/PresseService/Presse/Pressekonferenzen/2013/BIP2012/Statement_Egeler_2012 _PDF.pdf?__blob=publicationFile.

- Statistisches Bundesamt, 2012. Einwohnerzahl: 80,5 Millionen Einwohner am Jahresende 2012, https://www.destatis.de/DE/ZahlenFakten/GesellschaftStaat/Bevoelkerung/Bevoelkerungsstand/Aktuell.html

- $\quad$ Statistisches Bundesamt, 2014. Glosar - betriebliche Altersvorsorge. https://www.destatis.de/DE/Service/Glossar/B/BetrieblicheAltersvorsorge.html.

- Stern, 2014. So funktioniert die Betriebsrente, http://www.stern.de/wirtschaft/geld/bav-betrieblichealtersvorsorge-so-funktioniert-die-betriebsrente-1533265.html.

- Süddeutsche Zeitung, 2011. Wer sie nicht hat, verschenkt Geld, http://www.sueddeutsche.de/geld/betriebliche-altersvorsorge-wer-sie-nicht-hat-verschenkt-geld-1.1042815.

- Süddeutsche Zeitung, 2010. Wie sicher ist die Altersvorsorge? http://www.sueddeutsche.de/geld/leben-inder-krise-wie-sicher-ist-die-altersvorsorge-1.390557.

- Thaler, 1990. “Anomalies. Saving, Fungibility, and Mental Accounts”, in: Journal of Economic Perspectives, Volume 4, Issue 1, p. 193-205.

- Türkiye Cumhuriyeti Merkez Bankası (TCMB), 2014. Döviz Kurlar1. http://www.tcmb.gov.tr.

- Türkiye Cumhuriyeti Merkez Bankası (TCMB), 2013. Yurtiçi Tasarruflar ve Bireysel Emeklilik Sistemi: Türkiye'deki Uygulamaya ilişkin bir değerlendirme, Çalıma tebliği No: 13/04, http://www.tcmb.gov.tr/research/discus/2013/WP1304.pdf.

- Winnett and Lewis, 1995. "Households Accounts, Mental Accounts, and Savings Behaviour: Some Old Economics Rediscovered?”, in Journal of Economic Psychology, 16, p. 431-448.

- Versicherungsmagazin, 2012. 6,5 Milliarden Euro Potenzial. http://www.versicherungsmagazin.de/Aktuell/ Nachrichten/195/19944/6komma5-Milliarden-Euro-Potenzial.html.

- World Bank, 1994. Averting the Old Age Crisis. Policies to Protect the Old and Promote Growth. Oxford University Press, http://www-wds.worldbank.org/servlet/WDSContentServer/WDSP/IB/1994/09/01/ 000009265_3970311123336/Rendered/PDF/multi_page.pdf. 